\title{
IVAN TEIXEIRA
}

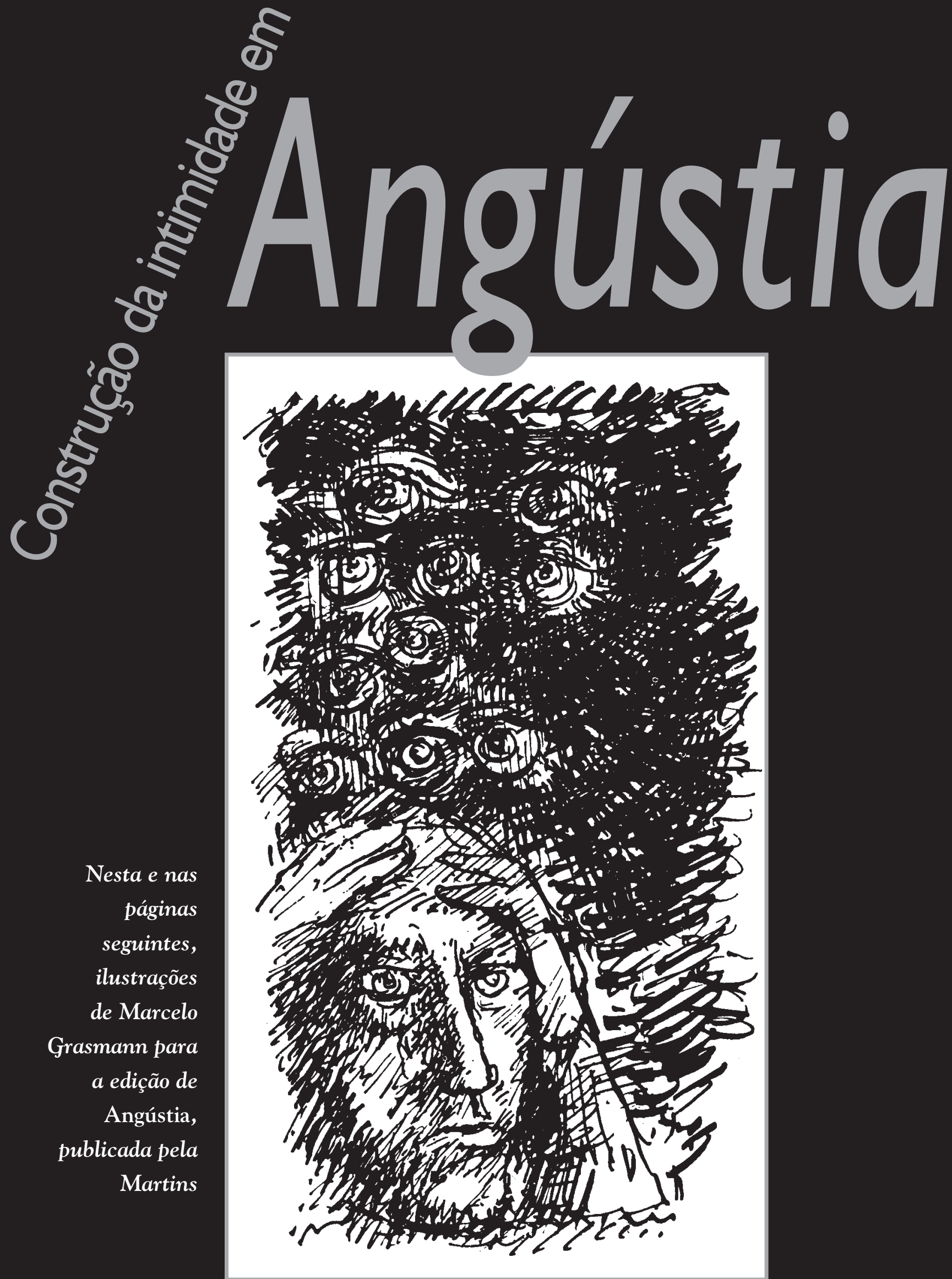


Parte do presente ensaio foi publicada pela Folha de S. Paulo, suplemento Mais!, com o título de "Angústia e Seus Autores", domingo, 7 de março de 2004, pp. 14 5. Agradeço a leitura crítica do pesquisador Tamis Parron, cujas sugestões, sempre amáveis e pre cisas, foram fundamentais para que o texto atingisse sua forma atual.

\section{ANGÚSTIA E SEUS AUTORES}

Angústia foi escrito entre 1933 e 1936, quando Graciliano Ramos era diretor de Instrução Pública em Maceió Segundo consta de seu discurso biográfico, estabelecido pelo próprio autor, Graciliano Ramos teria sido preso no mesmo dia em que entregou os manuscritos à datilógrafa, em março de 1936 (1). Em represália à rebelião da esquerda brasileira de novembro de 1935, o governo Vargas promovera indiscriminada onda de prisão por todo o Brasil. Nesse clima de instabilidade e autoritarismo é que Graciliano Ramos foi preso, sem processo nem acusação formal. Depois, seria conduzido para a Colônia Correcional de Dois Rios, na Ilha Grande (Rio de Janeiro). Sempre fora homem de inclinação democrática e espírito crítico, mas não pertencera ao Partido Comunista e nem estivera ligado àquela tentativa de golpe (2). Sua prisão não se fundou em nenhuma razão específica, exceto no fato de o escritor ser avesso às direitas autoritárias, então em franca ascensão no Brasil e no mundo (Facioli, 1987, p. 59). Angústia saiu em agosto de 1936 (3), quando o escritor estava na prisão, aos 44 anos.

Mas esse não é o único autor de Angústia. Há outros, instituídos pela própria condição do sistema ficcional da literatura, que pensa, imagina e cria independentemente da vontade ou da consciência do cidadão que produziu aquele artefato cultural. Como se sabe, em um romance, a apresentação da estória pode assumir inúmeras variações, de cujo conhecimento decorre a melhor ou pior apreensão do significado artístico da narrativa. Algumas dessas variações podem ser apreendidas por meio do alcance das respostas que o leitor consegue dar a algumas questões de caráter teórico, que envolvem, entre inúmeras outras, a noção de autoria, de narrador, de enredo, de fábula, de foco narrativo e de ponto de vista (4).

Para discutir a hipótese do segundo autor de Angústia, é preciso insistir um pouco mais no abc da teoria do discurso ficcional em prosa, começando pelo início: o que é enredo? É o que acontece com as personagens de uma narrativa,apresentada por uma voz a que se dá o nome de narrador. Escritor é aquele
IVAN TEIXEIRA

é professor de Cultura e

Literatura Brasileira no

Departamento de

Jornalismo e Editoração da

ECA-USP. É autor de, entre outros, Mecenato

Pombalino e Poesia

Neoclássica: Basílio da

Gama e a Poética do

Encômio (Edusp).
O episódio vem narrado no 3 capítulo de Memórias do Cárcere (Ramos, 1953, pp. 20-7).

2 Uma boa síntese da narrativa da prisão e soltura do autorpode ser lida em: Moraes, 1992.

3 Rio de Janeiro, Livraria José Olympio Editora.

4 Numa narrativa, nem sempre quem fala é quem vê. Nesse sentido, ponto de vista difere de foco narrativo, pois pressupõe a perspectiva segundo a qual se apresentam os elementos da estória, independentemente da voz que a apresenta. Em Vidas Secas, por exemplo, o foco narrativo é em terceira pessoa, mas o ponto de vista ou a perspectiva segundo a qual a coisas ficcionais se apresentam tanto pode ser de Fabiano quanto de Sinhá Vitória, dos dois meninos ou de Baleia. $O$ teórico da narrativa holandês Mieke Bal adota o termo focalizador para designar, com variações, o conceito de ponto de vista. Consultar bibliografia. 
que escreve; narrador é aquele que conta. O primeiro nem sempre é acessível ao leitor; o segundo estará sempre à sua disposição, desde que inicie a leitura de um livro. Assim, pode-se admitir que o primeiro autor de Angústia é o mesmo homem que, em outro momento, foi prefeito de Palmeira dos Índios. Como ocorre com qualquer escritor bem definido, em vez de conceber diretamente um narrador para Angústia, Graciliano Ramos inventou, antes, um escritor - o qual concebeu o narrador que apresenta a estória contida no livro. Esse primeiro escritor imaginado seria o segundo autor do romance, que, teoricamente, possui precedência sobre o homem Graciliano Ramos.

Conforme a mesma linha de raciocínio, o narrador de Angústia, Luís da Silva - que afirma ter vivido a estória contida no livro -, é o terceiro autor apresentado pelo cenário ficcional do romance. Sendo escritor inventado por um autor virtual, seria ingênuo supor que Luís da Silva viveu de fato o que afirma ter vivido. Como narrador que recompõe a própria vida pela escrita, deve ser interpretado como personagem que produz uma pseudo-autobiografia, a qual, em última análise, decorre da invenção e da elocução do escritor hipotético de Angústia, imaginado por Graciliano Ramos. Não obstante, a lógica da ficção literária obriga aceitar como verdadeira a estória inventada por esse autor, que a concebe como relato existencial de Luís da Silva. A admitir esse jogo de afirmação e de negação previsto pela gramática da composição artística de qualquer narrativa, tem-se de buscar o perfil ontológico dos três autores envolvidos em Angústia. Comece-se pelo escritor-narrador, que, funcionando como sujeito e objeto do cenário romanesco, possui uma espécie de anterioridade no processo imaginário de que emerge.

Núcleo desse xadrez de sombras e simulações, Luís da Silva é um intelectual solitário que, levado pelo desejo de escrever um livro, compõe uma trama em que figura como protagonista de uma estória de amor que termina em homicídio. Tendo imaginado experiências extremas para sua personagem, o escritor figurado pelo romance inventa um narrador que não consegue furtar-se ao impulso de escrever em primeira pessoa, como se compusesse um diário íntimo. Dominado pelo ciúme e pelo desejo de justiça, imagina-se como assassino de um homem rico que vivia seduzindo moças pobres e inseguras. Na trama do próprio livro, a personagem apaixonara-se pela vizinha Marina. Fez planos de casar com ela, entregando-lhe as exíguas economias para a preparação do enxoval. Depois de gastar o dinheiro em peças desnecessárias, a moça pretere o ansioso namorado e entrega-se a Julião Tavares, que a enche de presentes e de passeios encantadores. Com a vida financeira arruinada e com a autoestima em farrapos, Luís da Silva, dominado pelo álcool e por contínua sensação de pesadelo, estrangula Julião Tavares. Depois, levado pela necessidade de confissão, escreve a estória do próprio crime, em cujo texto se projeta a mesma atmosfera de delírio e fragmentação psicológica que praticamente o conduzira à loucura. Luís da Silva transforma-se numa espécie de homem-arte: matou para produzir literatura; inventou um amor para motivar o crime; depois, justificou o crime para fundar uma ética.

Essa ordem, que desfaz a intriga em favor da fábula, decorre da racionalização da leitura, que seleciona, corta, ata, intercala, reata e interpreta, porque vê tudo de fora, depois que tudo foi vivido e relatado pela personagem em desespero. Mas ela própria, que sentiu intensamente os acontecimentos que narra, não consegue organizá-los de maneira coerente. Para ela, tudo é confuso e caótico, porque, ao escrever, ainda se encontra emocionada com o que escreve, pois simula ter vivido o que escreve. Cada pormenor assume importância desmedida, até mesmo os olhos do gato que a espia do muro, horas depois do crime. $\mathrm{O}$ livro é organizado de modo a sugerir impressão de desarranjo e absurdo, pois procura representar as categorias subterrâneas de um indivíduo atormentado pelo isolamento e pela mania da auto-análise.

Se a posição de Luís da Silva se define facilmente, ainda que de forma singular, 
como personagem-narrador, cuja ação se condensa na composição de sua autobiografia, qual seria a relação entre Graciliano Ramos e o escritor que ele concebeu como inventor de Luís da Silva? Evidentemente, a relação é de semelhança, pois assim como Graciliano inventou o autor de Angústia, este inventou o agente e o criador de sua estória, cujo núcleo é a redação do próprio livro (Baptista, 1993). Todavia,olivroimaginado pelo autor hipotético e escrito por Luís da Silva aparece, nas livrarias, assinado por Graciliano Ramos. Desenvolvendo premissas de um livro renovador na crítica de língua portuguesa (Baptista, 2003) - finalmente algo de novo e teoricamente sustentável sobre Machado de Assis! -, o ensaísta português Abel Barros Baptista abordou essa questão em instigante artigo sobre São Bernardo. Assim, segundo a lógica artística, que atribui precedência aos componentes ficcionais do discurso literário, o homem que redigiu Angústia pode e, em certo sentido, deve ser concebido como criação de suas páginas. Pois, para se tornar artista, o homem Graciliano Ramos teve, primeiro, de conceber suas criaturas ficcionais, que o instituem como inventor de estórias. Caso não as escrevesse, o diretor de Inspeção Pública de Maceió não se agregaria ao mundo da ficção brasileira. Logo, sua condição de escritor é inventada pelos livros que escreveu.

Assim, o escritor Graciliano Ramos, que difere integralmente do homem, deve ser concebido como efeito de sua ficção, istoé, como resultado dos componentes da poética cultural segundo a qual construiu o discurso que propicia e condiciona sua existência como artista. Essa hipótese não o afasta da História nem das contingências sociais. Ao contrário, aproxima-o ainda mais da realidade de seu tempo. Visto dessa maneira, o artista converte-se em encarnação viva do discurso cultural de uma época, que envolve tanto noções de ética e de ideologia especificamente consideradas, quanto concepções de arte e princípios de técnica construtiva. De onde se extraem as características do perfil estilístico, temático ou ideológico de um artista senão da obser- vação de sua obra? Se isso vale para a descrição tradicional dos artistas (um construto cultural como tantos outros), por que não admitir que Graciliano Ramos é invenção de suas próprias obras? Segundo esse raciocínio, o primeiro autor hipotético de $A n$ gústia não só imaginou o escritor-narrador Luís da Silva, como também inventou o autor cujo nome aparece nos livros que servem de suporte material para a ficção de seu romance. Assim, o primeiro escritor hipotético, aquele que cria a personagem Luís da Silva, identifica-se com o artista Graciliano Ramos, que não se confunde, digamos, com o pai de Ricardo Ramos. Trata-se, antes, de uma entidade cultural, estilizada pelo hábito de escrever e resultante de seu repertório ético, estético, técnico, ideológico, político e sociocultural.

\section{TIPOLOGIA DO INVENTADO}

Do ponto de vista da tipologia tradicional, oferecida por Edwin Muir (s/d, pp. 102) e acatada por influente estudioso brasileiro (5), Angústia poderia ser classificado como romance dramático, porque sua ação decorre de uma psicologia previamente estabelecida pela arte de Graciliano Ramos. Wolfgang Kayser (1976, pp. 4023) e outros autores mais recentes - como Northrop Frye (1997, p. 324) (6), por exemplo - chamam romance de personagem (7) ao que Muir caracteriza como romance dramático. Qualquer que seja a classificação adotada, o que importa é que Angústia deve ser entendido como romance de construção da intimidade, e não de análise psicológica. De fato, não se trata propriamente de análise psicológica, como afirma a crítica tradicional, porque Luís da Silva não existe, é personagem de ficção. Trata-se, antes, de construção psicológica, no sentido de o romance resultar do miolo da personagem como invenção de uma mentalidade, com destaque para seus pensamentos, sentimentos, frustrações, dores, ódios, lembranças, desejos, imagens, visões, sonhos e delírios.

\footnotetext{
Massaud Moisés. Ver nota 7

6 Vítor Manuel de Aguiar e Silva (1984, p. 685) segue o conceito de Kayser e Frye. A narratologia pós-estruturalista não se preocupa com esse tipo de classificação

Edwin Muir defende a idéia de que o romance de personagem se funda no jogo de cena com caracteres planos, na definição de Forster, que já surgem completos no início da estória, e cuia existência se justifica apenas como cenário genérico para o desfile variado das personagens. Fundado nessa detinição, Massaud Moisés (1970 pp. 258-9) apresenta O Primo Basilio e A llustre Casa de Ramires, de Eça de Queirós, como manifestações acabadas de romance de personagem, entendido como moldura para a apresentação de caracteres estáticos
} 
Como convém aos romances voltados para a construção da intimidade, a ficcionalização da memória e do tempo é componente fundamental à estrutura de Angústia . Nesse sentido, seu modelo mais ilustre talvez sejam as Confissões, de Santo Agostinho (Ricoeur, 1984,pp.3-30). Como tudoé fluido e contínuo na lembrança das pessoas, Angústia não apresenta divisão em capítulos, e sim pequenas lacunas entre grandes sequiências de significado coeso, traço formal que pretende insinuar a continuidade $\mathrm{e}$ a fluidez da mente no processo de reinventar o vivido, movimento que vem em ondas, interrompido apenas por breves intervalos. Por começar onde termina, podese afirmar que o romance possui estrutura circular e ininterrupta, simulando imitação do estado psíquico de pessoa dominada por idéia fixa, em torno da qual flutua uma infinidade de outras idéias e imagens correlatas.

Conforme a narratologia atual, Angústia aceita igualmente a classificação de narrativa autoconsciente (Culler, 2001), porque o gesto da composição artística integra de forma decisiva o cenário das invenções ficcionais de seu autor imaginado. Tradicionalmente, a referência ao ato de escrever chama-se metalinguagem, porque, em vez de se referir à vida das personagens, o narrador, em tais passagens, refere-se à própria linguagem que inventa aquelas vidas, ainda que, no caso dessa obra, o faça de forma especular, referindo-se, não ao romance propriamente dito, mas a outros textos que escreve paralelamente à ação central da narrativa, que é a invenção e a elocução do próprio romance (8). Como se sabe, o processo de auto-referência ocorre em qualquer tex to escrito, desde a Antigüidade. Mas tornou-se um dos motivos preferenciais do romance contemporâneo, sistematizando-se a partir do período realista, no século XIX. Manifesta-se com muito relevo em Angústia, tal como se percebe desde o início do relato de Luís da Silva, quando, tendo de produzir um artigo para o jornal em que trabalha, escreve:

“À noite fecho as portas, sento-me à mesa da sala de jantar, a munheca emperrada, o pensamento vadio longe do artigo que me pediram para o jornal.

Vitória resmunga na cozinha, ratos famintos remexem latas e embrulhos no guardacomida, automóveis roncam na rua.

Em duas horas escrevo uma palavra: Marina. Depois, aproveitando letras deste nome, arranjo coisas absurdas: ar, mar, rima, arma, ira, amar. Uns vinte nomes. Quando não consigo formar combinações novas, traço rabiscos que representam uma espada, uma lira, uma cabeça de mulher e outros disparates. Penso em indivíduos e em objetos que não têm relação com os desenhos: processos, orçamentos, o diretor, o secretário, políticos, sujeitos remediados que me desprezam porque sou um pobre diabo. [...] Afinal tudo desaparece. E, inteiramente vazio, fico tempo sem fim ocupado em riscar as palavras e os desenhos. Engrosso as linhas, suprimo as curvas, até que deixo no papel alguns borrões compridos, umas tarjas muito pretas" (Ramos, 1936, pp. 6-8).

Como se sabe, esse tipo de narrativa pode também ser chamado de romance de enunciação, porque o gesto de composição da escrita, que será imitada na redação global da obra, reincide muitas vezes na estória que se conta. Aliás, essa parece ser a melhor classificação de Angústia . Todavia, em termos explícitos, a enunciação do romance não se dá exclusivamente pela escrita, mas também pelo simples ato de mentar do narrador: pois ora ele expõe a matéria de seu livro por meio da simulação de vivências sem registro, como se as estivesse vivendo no momento em que as inventa; ora a expõe como registro de ações supostamente ocorridas no passado; ora como longas seqüências de alucinações que se explicitam como resultado de desejo, de medo ou da permanente incerteza em que vive.

Como se vê pelo fragmento, figurar a enunciação - o ato de produzir enunciados - envolve tanto a escolha e a apreensão da matéria quanto o falar sobre ela. Normalmente, tal procedimento incorpora reflexões sobre o conceito, a função e a estrutura da obra literária. Do ponto de vista 


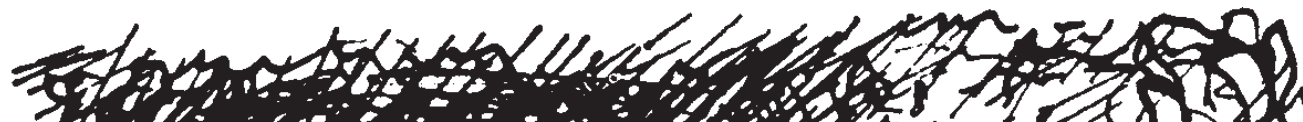
(4) 5. oi,

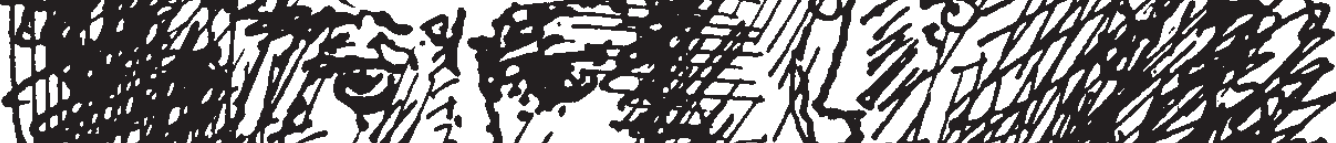
(1.

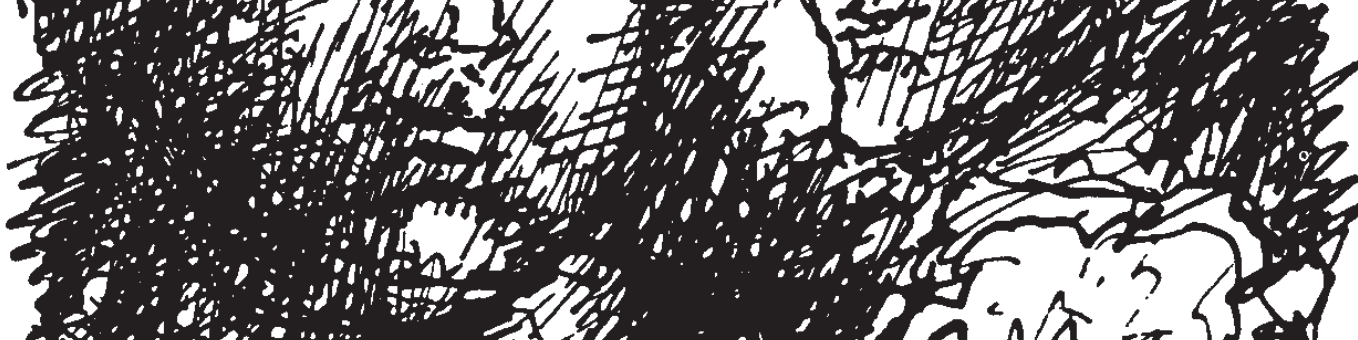

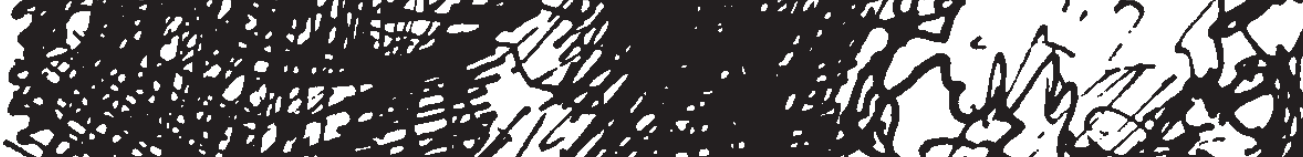

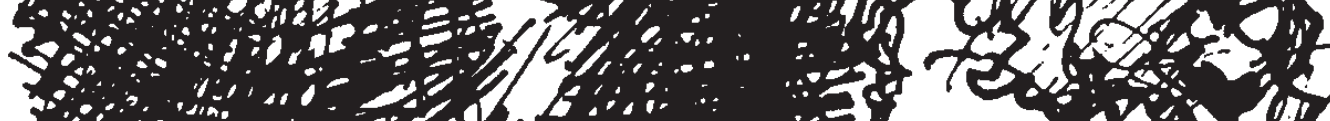
*

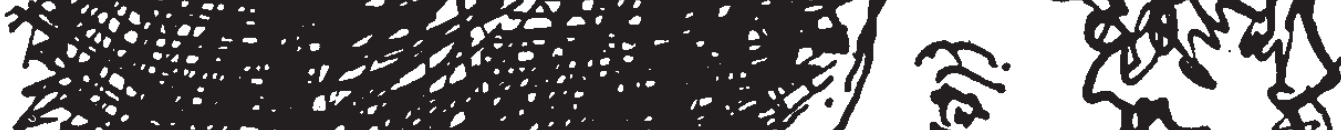
(1)

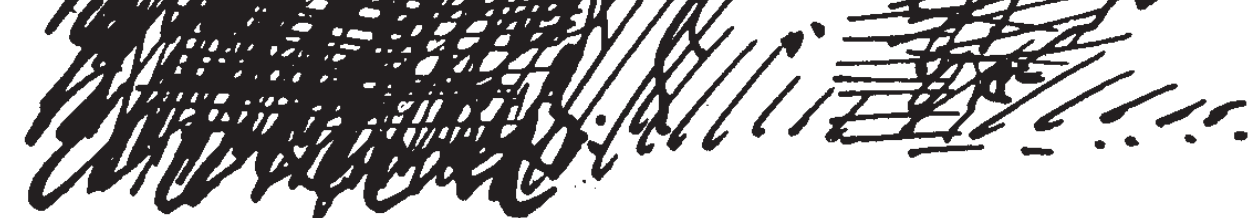


semiótico, as montagens anagramáticas com as letras do vocábulo Marina insinuam a instauração dos componentes semânticos do dilema de Luís da Silva, correspondendo à sua contínua asfixia moral (ar e mar), ao refúgio na atividade literária (rima), ao desejo de aniquilar Julião Tavares (arma), ao ódio contra o mundo (ira) e ao móvel essencial da trama de seu livro: o amar, que se transforma nas demais variantes do nome e com elas se confunde, culminando com a grande vitória da redação do livro, ambição que decorre de espontânea vocação do protagonista para as letras desde a primeira juventude, quando, em meio à extrema escassez de condições , consegue impor-se como professor rural no sertão de Alagoas.

Angústia partilha, ainda, da natureza da enunciação performativa, caracterizada pela instituição imediata das coisas no momento mesmo em que as palavras ganham corpo no texto. Assim, a realidade da obra confunde-se com o registro das coisas no momento mesmo em que são inventadas, como se os supostos acontecimentos brotassem das palavras do protagonistaescritor, tal como prescreve a noção de texto performativo (Culler, 1992). Nesse sentido, Angústia não conta propriamente uma estória; antes, constrói uma personalidade poderosa, cujo desenho ocupa a atenção central do autor ficcional. Sendo personagem-narrador, Luís da Silva projeta toda sua singularidade no texto, atribuindo-lhe a condição de reflexo de uma ficção. Logo, o texto tanto pode ser pensado como imagem virtual de uma psicologia imaginária quanto como configuração real de palavras de onde emerge o desenho verossímil da mente que a teria gerado. Visto que o narrador do romance se deixa interpretar como um escritor fictício cuja narrativa simula a vida de quem a escreve, a obra encarna o próprio conceito de arte, que prescinde de matriz realista imediata, imitando antes modelos, estruturas ou discursos da tradição do que propriamente situações empiricamente demonstráveis. Ao justificar a presença de uma faixa de tinta verde no rosto de uma de suas figuras femininas,
Henri Matisse afirmou que desejava compor um quadro, e não criar uma mulher (Cole \& Gealt, 1991, p. 265). Logo, o que realmente interessa no romance são os limites do próprio livro, que se alargam infinitamente na medida em que envolvem a maturação de um problema pessoal, entendido como referente do fingimento artístico posto em cena pelo sujeito da narrativa.

\section{ABISMO DO ROMANCE}

Conforme esse argumento, Luís da Silva confunde-se com o próprio efeito de angústia programado pelo romance. De fato, o relato de Luís da Silva emaranha-se visceralmente com sua vida: as propriedades de seu caráter determinam a ação do livro, assim como os acidentes da enunciação acabam por alterar as disposições de seu caráter. Tudo depende de sua voz criadora, porque ele é narrador dominado pelo propósito de construir um texto à imagem e semelhança dos fantasmas de seu mundo subterrâneo. Nesse sentido, talvez a noção que melhor o caracterize, enquanto intimidade construída, seja misantropia, entendida como grau doentio de solidão e isolamento. Essa anomalia comportamental possui origens na infância desolada e na decadência do ambiente familiar: avô bêbado e caduco; pai inerte e dependente. Ao relatar sua infância, nada diz sobre a mãe, embora forneça informes sobre as mulheres que o rodearam nos tempos de formação. Ela é aludida apenas na parte final do romance, quando compõe a profunda letargia em que caiu depois de assassinar Julião Tavares. Como evoca a mãe somente na inconsciência, presume-se que seu contato com ela se tenha dado apenas no útero ou no estágio em que era bebê.

Embora fundado em estrutura labiríntica, não se trata, propriamente, de um livro dentro de outro livro, como faz crer a frase de Jacques Derrida, escolhida por Lúcia Helena Carvalho (1983, p. 5) como mote para o belo conceito de Angústia como um romance de "construção em abismo". Essa 
parece ter sido a noção mais adequada até hoje apresentada para o entendimento dessa obra de Graciliano Ramos. Em favor do argumento da própria ensaísta, talvez fosse mais verossímil evitar a idéia do suposto crime de Luís da Silva como a ação nuclear da narrativa (Carvalho, 1983,p. 26). Ao contrário, o motivo central do romance parece ser mesmo o desejo de escrever um livro, exposto em diversas passagens do fluxo mental de Luís da Silva, particularmente no episódio em que acompanha o banho de Marina, pouco antes de saber da gravidez provocada pela usurpação de Julião Tavares:

"Enquanto estou ali fumando, nu, as pernas estiradas, dão-se grandes revoluções na minha vida. Escrevo um livro, um livro notável, um romance. Os jornais gritam, uns me atacam, outros me defendem. O diretor olha-me com raiva, mas sei perfeitamente que aquilo é ciúme e não me incomodo. Vou crescer muito. Quando o homem me repreender por causa da informação errada, compreenderei que se zanga porque o meu livro é comentado nas cidades grandes. E ouvirei as censuras resignado. Um sujeito me dirá:

- Meus parabéns, seu Silva. O senhor escreveu uma obra excelente. Está aqui a opinião dos críticos.

- Muito obrigado, doutor"' (Ramos, 1941, p. 186).

No princípio, a idéia do romance surge apenas como desejo vago ou sublimação doentia. Depois, vai se transformando em projeto consciente, cada vez mais incrementado pela contínua prática em outras modalidades de escrita, cuja enunciação surge e ressurge como matéria intercalada na narrativa do livro. Como ocorre com qualquer narrativa, a de Luís da Silva necessariamente envolve a imitação de uma idéia de ação, de um sujeito que a pratique e de uma paixão ou motivação psicológica que a torne homóloga à prática humana que se representa, respeitando o código artístico especificamente adotado: o do romance contemporâneo - quer se caracterize pela construção da intimidade, pela ênfase na auto-referência, pelo relevo atribuído à análise da enunciação ou pela adoção da linguagem performativa.

Por essa perspectiva, toda substância extraliterária de Angústia - quer se entenda a expressão como sociedade, ideologia, política, autobiografia ou psicanálise-será sempre literária, será sempre traduzida em termos de referencialidade discursiva, e não em termos de cópia ou de reflexo de coisas anteriores à sua incorporação a uma poética da cultura em geral e a um sistema de signos literários em particular. A admitir tal premissa como hipótese suplementar à metáfora do romance como construção abissal, seria razoável excluir do universo de sua ficção qualquer hipótese de "realidade objetiva dos fatos" (Carvalho, 1983, p. 23). Embora aceitável em outro tipo de argumentação, essa idéia contraria o princípio do romance como imitação do romance, pressuposto básico para a compreensão de Angústia como construção de arte literária, e não apenas como projeção artística de verdades psicológicas de Graciliano Ramos, como sugere Antonio Candido (1956, p. 50) em seu ensaio pioneiro-e ainda hoje estimulante - sobre o livro.

\section{NECESSIDADE, TRANSGRESSÃO}

Como Angústia explora, no nível da fábula, o desejo e o projeto da redação de um livro sobre um assassinato, seu assunto pode ser o crime de Luís da Silva, motivado pelo amor a Marina e pelo ódio a Julião Tavares. Como se sabe, o assunto de um romance coincide com a matéria específica de sua composição artística, sem a intervenção crítica da interpretação, que agrega sentidos e levanta hipóteses. Quando se interpreta o assunto, ampliando sua significação, chega-se ao tema. O tema, portanto, é o assunto interpretado, que assume significações mais abstratas e mais abrangentes, devendo ser associado ao repertório de tópicas consagradas pela tradição literária, e não necessariamente a incidentes 
semelhantes que porventura se conheçam na vida prática. Ou seja, o tema ou sentido geral de um romance decorre de sua associação com outros romances ou com outras categorias discursivas. Assim, embora o conceito de arte se imponha a cada instante, pode-se dizer que o tema de Angústia se confunde com o estudo das conseqüências de um amor frustradoe doentio, como aquele estabelecido pela tradição instaurada por Goethe em Werther. Trata-se, ainda, de uma investigação da tópica do ciúme, entendido como forma degenerada de amor, abordado anteriormente por Graciliano em São Bernardo, que, por sua vez, é um redimensionamento de Dom Casmurro, parcialmente inspirado em Otelo.

Como matéria de invenção romanesca, o ciúme do protagonista pode ser interpretado como resultado da profunda solidão em que vive, de cuja atmosfera decorre sua atitude desesperada. Por outro lado, podese pensar também numa espécie sertaneja de amor cortês brutalizado, na medida em que é possível entender o sentimento de Luís da Silva como entrega total à contemplação da amada - o que, de alguma forma, o aproxima da maneira petrarquista de conceber o amor, ainda que só consiga enquadrar a mulher em categorias rebaixadas de idealização. Depois da decepção amorosa, Luís da Silva não fez outra coisa senão admirar e desejar Marina a distância, terminando por empregar toda sua energia na punição daquele que a prejudicou. Antes, porém, impôs-se o poético trabalho de compor idealmente a mulher por quem mataria, tal como se vislumbra nessa passagem do romance, que também põe em cena o gesto da enunciação em si:

"Naturalmente gastei meses construindo esta Marina que vive dentro de mim, que é diferente da outra, mas se confunde com ela. Antes de eu conhecer a mocinha dos cabelos de fogo, ela me aparecia dividida numa grande quantidade de pedaços de mulher, e às vezes os pedaços não se combinavam bem, davam-me a impressão de que a vizinha estava desconjuntada. Agora mesmo temo deixar aqui uma sucessão de peças e de qualidades: nádegas, coxas, olhos, braços, inquietação, vivacidade, amor ao luxo, quentura, admiração a d. Mercedes. Foi difícil reunir essas coisas e muitas outras, formar com elas a máquina que ia encontrar-me à noite, ao pé da mangueira” (Ramos, 1936, pp. 92-3).

Qualquer que seja o encaminhamento da questão sobre o sentido geral do romance, não se pode ignorar que o tema de $A n$ gústia gira em torno do amor, do ciúme, da contemplação, do desejo, da solidão, do ódio e do crime, categorias relacionadas por oposição e por complementaridade.

Embora se considerasse "um pobre diabo", o protagonista foi capaz de chegar ao extremo dos homens fortes, eliminando aquele que prejudicara a mulher de seus sonhos e inviabilizara o propósito de união com ela. Mesmo na miséria, escrevia sonetos. Essas contradições fazem de Luís da Silva uma personagem surpreendente, espécie de símbolo literário da revolta. Seu êxito decorreu do culto da consciência da fragilidade. De tanto remoer a própria condição que inventou como verdade de seu estatuto ficcional, passou a conhecer-se integralmente. Desse conhecimento the veio força para superar seu estado de extrema insuficiência: "Habituei-me a escrever, como já disse. Nunca estudei, sou um ignorante,e julgo que os meus escritos não prestam. Mas adquiri cedo o vício de ler romances e posso, com facilidade, arranjar um artigo, talvez um conto" (Ramos, 1936, p. 59).

Apesar da descriçãomiúdada penúria em que vive a personagem, no final resulta a impressão de que Luís da Silva é vitorioso. Mas nem por isso Angústia deve ser entendido como apologia explícita do crime,embora deixe margem para supor que, em alguns casos, a subversão de todos os padrões impõe-se como única saída aceitável. Por isso, é possível entender o romance como problematização ficcional da noção de crime, pois o leitor não deseja a punição de Luís da Silva, embora o considere criminoso.

Paralelamente, o romance investiga os mecanismos subjetivos que levam o assassino a justificar o próprio delito. Perante a 
consciência do protagonista, o assassinato impôs-se como espécie subjetiva de legítima defesa. Caso não agisse, é possível que morresse, pois o ódio acabaria por corroer seu sistema nervoso. Nesse sentido, o crime o livrou da inércia que o conduziria à morte impulsionando-o, igualmente, à concretização do antigo sonho de escrever um livro. A realização do ideal artístico acaba por consolidar a conquista da simpatia do leitor. Além disso, o narrador se apresenta como vítima de um grande amor interrompido.

\section{NÃO CONFIÁVEL}

Todavia, terminada a leitura, surge hipótese desfavorável a ele: não será um criminoso vulgar, que, para legitimar o crime e obter a absolvição ideal do leitor, desclassifica o opositor, descrevendo-o em termos repulsivos? Do ponto de vista literário, o confronto das duas hipóteses interpretativas da posição de Luís da Silva faz dele um narrador não confiável (Booth, 1961, pp. 158-9) (9), tal como Bento Santiago, em Dom Casmurro, e Paulo Honório, em São Bernardo, entre tantos outros.

Além de possibilitar a problematização das tópicas abordadas, esse tipo de narrador não delimita com precisão os contornos da própria estória, gerando obra inconclusa e fragmentada, propriedades positivas conforme o código da arte contemporânea. Por essa perspectiva, é possível duvidar das afirmações de Luís da Silva, inclusive da veracidade do crime que alega ter cometido. A posição dúbia do narrador admite a hipótese segundo a qual a fábula de sua narrativa não contém senão os delírios de um misantropo alucinado por desejos que não consegue realizar. Tais aspectos todos indiciam a apropriação técnica da engenharia do estilo expressionista, entendido como a formulação de impressões que deformam a ordem discursiva do real aparente, à maneira das pinturas de Klimt, Schiele, Munch ou Kirchner (Cole \& Gealt, 1991, pp. 261-71), o que não descarta, antes pressupõe, o redimensionamento cons- ciente de tópicas e procedimentos do Naturalismo oitocentista, tais como a degradação do espaço externo, que coincide com o desalento psicológico do narrador, e a incorporação do sexo como manifestação espontânea, em contínua luta por se afastar da esfera da cultura e se aproximar dos utópicos domínios da natureza. Nesse sentido, até as personagens do romance não passariam de projeção do universo psíquico do narrador, propenso a confundir os fatos que imagina como reais com os delírios de seu cérebro doentio, também reais como fatos de ficção (10). É o que se infere do entendimento de Luís da Silva como romancista imaginário cuja narrativa simula a própria vida. Nesse sentido, Angústia ajusta-se à concepção segundo a qual o romance é um agente semiótico que viabiliza a inteligibilidade do mundo (Culler, 1993).

Em sentido divergente, haverá, ainda, quem pretenda entender Angústia como possível alegoria política da luta de classes, sob o argumento de que Luís da Silva, oprimido funcionário do Estado capitalista, insurge-se contra a burguesia comercial, representada por Julião Tavares. Conforme essa interpretação, o crime de Luís da Silva representaria a aurora da revolução comunista, que vinha sendo planejada no Brasil desde 1922 e que teve seu início frustrado nas rebeliões de 1935. Embora engenhosa, essa interpretação força alguns elementos concretos da estrutura da obra, valendo-se principalmente de circunstâncias culturais da vida literária brasileira do período do romance e do tempo de sua fábula. A acreditar na hipótese da alegoria política, o romance deveria ser interpretado como espécie de propaganda artística do comunismo, o que contraria as convicções do próprio narrador, que não partilhava das idéias de seu amigo Moisés, este, sim, partidário da revolução armada. Também Graciliano Ramos, enquanto artista e homem público, em mais de uma ocasião expressou opinião contrária ao romance engajado, então muito estimulado pela União Soviética e do qual há ecos consideráveis na produção de Jorge Amado, por exemplo. Em vez de aderir ao romance
9 Vertambém:Culler, 1997, p. 89 Hawthorn, 1993, pp. 66-7

10 Em sentido semelhante, mas com conclusões diferentes, Álvaro Lins (1963, p. 150) afirma sobre Angústia: "Os outros personagens são projeções do personagem principal ${ }^{\prime \prime}$ 
panfletário, o artista preferiu incorporar à ficção de Angústia o secular debate sobre a função da obra de arte, por meio de respostas do narrador a estímulos do discurso cultural do ambiente político brasileiro da época, desenhado no romance. Mais ou menos no final do livro, lê-se a seguinte observação de Luís da Silva: “A tecla de sempre, arte como instrumento de propaganda política. Eu queria contrariar o judeu, mas esmorecia, sem coragem para a discussão" (Ramos, 1936, p. 229).

Mesmo contra a consciência do narrador, ele talvez pudesse simbolizar a revolta inconsciente do povo, organizada por uma eventual elite ideológica. Ocorre que a ideologização das atitudes não faz parte da trama ficcional do romance, sendo certo que Luís da Silva era homem de idéias, e esta não consta de seu repertório. Caso se insista em sustentar o entendimento do romance como alegoria da revolução antiburguesa, não se pode ignorar que o núcleo significativo de sua fábula consiste na exploração do tema do amor frustrado e na reflexão sobre a legitimidade do crime em situações extremas. A alegoria política, apesar de violentar certos elementos estruturais da obra, poderia ser discutida apenas como insinuação paralela, jamais como a motivação central do romance.

\section{PARADIGMAS}

Embora Machado de Assis e Aluísio Azevedo tenham oferecido diversas sugestões à concepção e à redação de Angústia, nenhum desses escritores teria condições técnicas de baralhar o tempo e fragmentar a noção de realidade tal como o fez Graciliano Ramos. De Machado de Assis Angústia aproveita agilidade da frase curta e a habilidade na construção psicológica de um indivíduo complicado. A presença de Aluísio Azevedo dá-se por meio da ênfase à miséria social do ambiente. Em alguns momentos, a descrição da casa, dos vizinhos e da rua de Luís da Silva lembra o

cenário de $O$ Cortiço. Gente pobre, deter- minada pelas condições, vivendo em casas contíguas, com esgoto aberto e com pouco dinheiro - isso é comum aos dois romances, embora em $O$ Cortiço seja caracterizado com mais pormenor. Outro aspecto comum é a atenção dada à espontaneidade do sexo. Luís da Silva esfregava Marina no fundo do quintal, desejando possuí-la ali mesmo, no escuro da noite. Antônia, uma empregada da vizinhança, vivia entregue aos desejos insatisfeitos com diversos namorados. Em frente à casa de Luís, morava um velho do qual se dizia que vivia maritalmente com as três filhas. Enfim, há diversas cenas de sexo espontâneo, o que lembra as preferências temáticas do Naturalismo, com algumas configurações próprias do Expressionismo, conforme se verá adiante.

No plano internacional, Angústia apresenta parentesco com Crime e Castigo, de Dostoiévski (11). Como se sabe, esse romance narra o crime de um estudante, Raskólnikov, que se convenceu de que era eticamente sustentável assassinar uma velha agiota para se apropriar do dinheiro dela. Na consciência do estudante, a velha era indigna da própria fortuna, ao passo que ele, com dotes superiores de cultura e inteligência, não a possuía, mas a merecia. Por isso, assassina a mulher, pensando que não teria crise de consciência. Mas as coisas não saem conforme os planos, e o estudante entra em processo de instabilidade emocional delirante, corroído pela dúvida e pelo remorso.

As condições de Luís da Silva são semelhantes às de Raskólnikov, embora o brasileiro não tenha tido nenhum remorso ou sentimento de culpa, pois considerava que seu crime, mais do que necessário, era inevitável. Raskólnikov mata essencialmente por dinheiro, apesar de enumerar diversas outras razões perante a própria consciência: afinal de contas, para pegar o dinheiro ele assassinou também a irmã da usurária, tida como pura pela lógica da fábula e que surgiu inesperadamente na cena do crime. Pelos limites estritos da fábula, Luís da Silva mata por ciúme e por ódio, sentimentos que procura revestir com a idéia asocia oposição, ça ou parentesco. 


\section{Fit:-

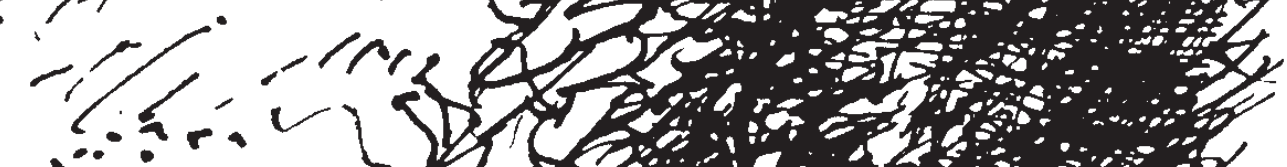 \\ $\because \because n$ r.

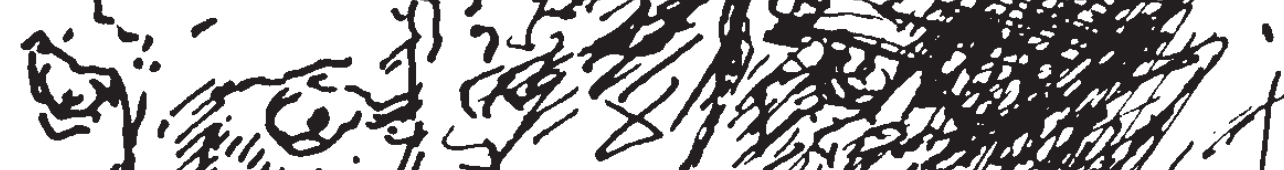

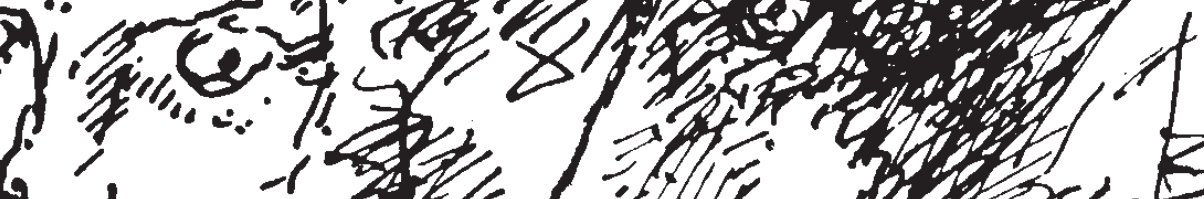 G', -

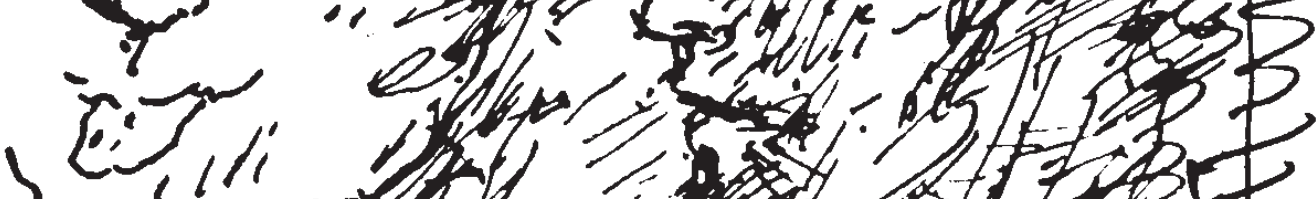 ᄂ.11i Ut}

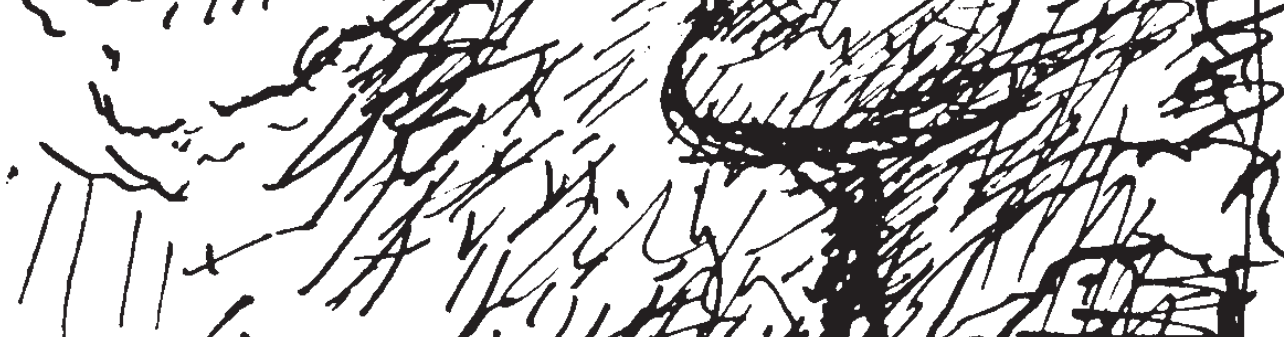

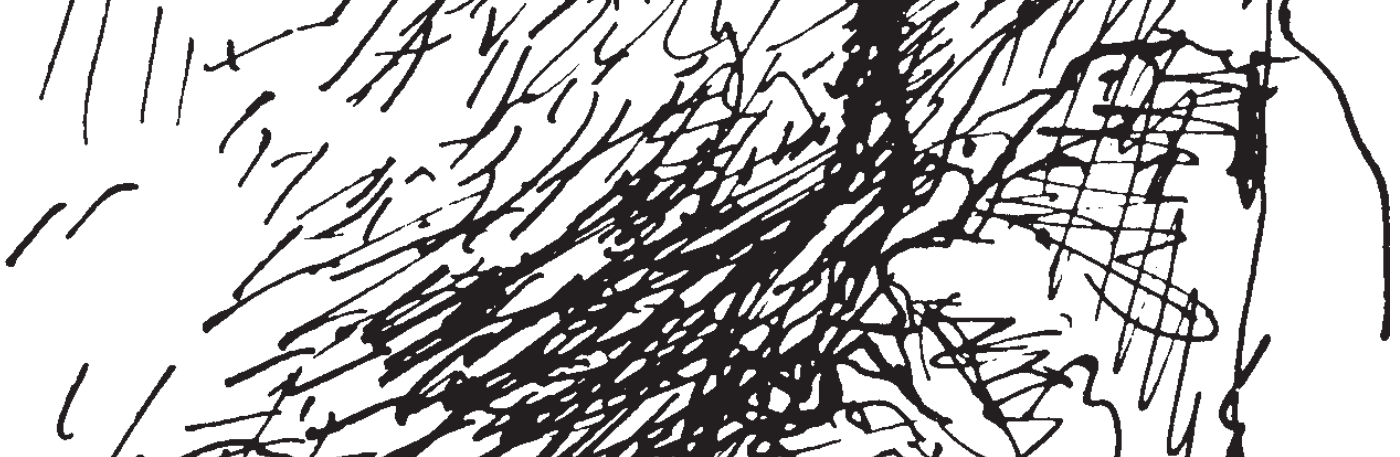

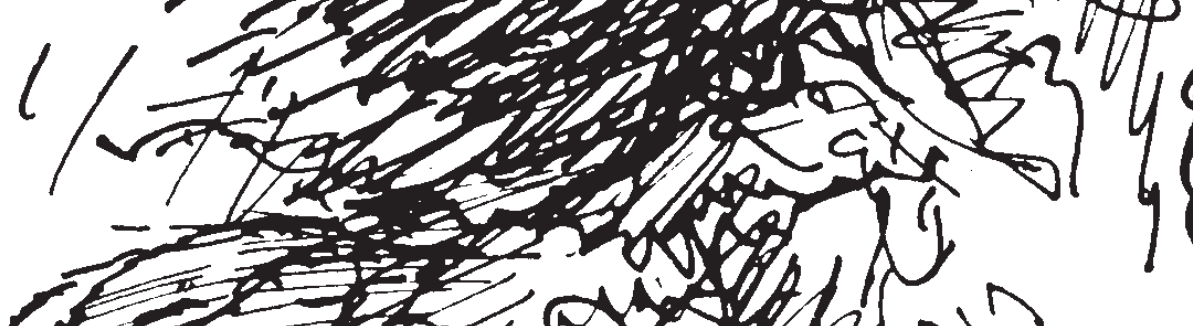
comis 
12 Partilhando de pressupostos críticos de seu tempo, esse ensaio admirável em diversos sentidos, não estabelece nítida diferença entre escritor e narrador na obra machadiana.

13 Em seu "Prefácio do Tradutor", Boris Schnaiderman prefere a ex pressão "homem do subsolo" em vez de "homem subterrâneo". de justiça. Assim como ocorreu com Raskólnikov, o crime de Luís da Silva acentua sua instabilidade, conduzindo-o a vertigens dolorosas, em que idéias e sensações compõem um sofrido caleidoscópio de vivências interiores. É nesse sentido que os romances mais se aproximam, isto é, na arte de compor um possível painel do labirinto psicológico de criminosos que procuram justificar intelectualmente suas ações.

Todavia, o modelo retórico mais próximo de Luís da Silva talvez seja o narrador anônimo da novela Memórias do Subsolo, também de Dostoiévski, de onde deriva a expressão “homem subterrâneo”, consagrada em português como categoria crítica para designar narradores dominados por uma espécie de ódio conceitual que às vezes se converte em indiferença, pela mania de isolamento e pelo contínuo impulso de auto-análise. Tal como em Memórias do Subsolo, o sujeito da enunciação de Angústia começa por se declarar doente, isolado e com raiva de si próprio e do mundo exte- rior. No Brasil, Augusto Meyer parece ter sido o primeiro ensaísta a abstrair as propriedades do narrador de Dostoiévski para instituí-las em princípio crítico, aplicandoas na descrição da inércia contemplativa de certos aspectos da persona literária identificada como Machado de Assis, num pequeno ensaio intitulado justamente "O Homem Subterrâneo” (Meyer, 1958,pp. 11-9) (12). Depois, Antonio Candido associou explicitamente onarradorde Dostoiévski aLuís da Silva, ainda que o interpretasse mais como um tipo social e psicológico do que como modelo de construção literária (Candido, 1971 , p. 108). No prefácio de sua tradução da novela russa para o português (Dostoiévski, 2000), Boris Schnaiderman, baseado em Mikhail Bakhtin, alude ao conceito de homem subterrâneo como dispositivo artístico para a elaboração de literatura conceitual, fundada basicamente na interdiscursividade (13). A pequena genealogia dessa espécie de narrador estende-se, com muita lucidez, às orelhas do volume, assinadas por Manuel da Costa Pinto.

\section{BIBLIOGRAFIA}

AGUIAR E SILVA, Vítor Manuel. Teoria da Literatura. 6a ed. Coimbra, Livro Almedina, 1984, vol. 1.

BAL, Mieke. Narratology: Introduction to the Theory of Narrative. Second edition. Translated by Christine Van Boheemen. Toronto/Buffalo/London, University of Toronto Press, 1999.

BAPTISTA, Abel Barros. A Formação do Nome: Duas Interpretações sobre Machado de Assis. Campinas, Editora da Unicamp, 2003.

. "Na Torre da Igreja uma Coruja Piou... Autor Ficcional e Ficção do Livro em 'São Bernardo'", in Colóquio/Letras, no 129/130, julho/dezembro, 1993, pp. 159-81.

BECKSON, Karl \& GANZ, Arthur. A Reader's Guide to Literary Terms. London, Thames and Hudson, 1972.

B00TH, Wayne C. The Rhetoric of Fiction. Chicago/London, The Chicago University Press, 1961.

BRAYNER, Sônia (org.). Graciliano Ramos: Fortuna Crítica. Rio de Janeiro/Brasília, Civilização Brasileira/INL/MEC, 1977. CANDIDO, Antonio. Ficção e Confissão - Ensaios sobre a Obra de Graciliano Ramos. Rio de Janeiro, José Olympio, 1956. "Os Bichos do Subterrâneo", in Tese e Antítese: Ensaios. 2. ed. rev. São Paulo, Companhia Editora

Nacional, 1971.

CARVALHO, Lúcia Helena. A Ponta do Novelo: uma Interpretação de Angústia, de Graciliano Ramos. São Paulo, Ática, 1983.

COLE, Bruce \& GEALT, Adelheid. Art of the Western World: From Ancient Greece to Post-Modernism. New York/ London/Toronto/Sydney/Tokyo/Singapore, Touchstone Book, 1991.

CRISTÓVÃO, Fernando Alves. "0 Tempo, os Tempos e os Planos da Narração", in Graciliano Ramos: Estrutura e

Valores de um Modo de Narrar. Apud José Carlos Garbublio e outros (orgs.). Graciliano Ramos: Antologia e

Estudos. São Paulo, Ática, 1987, pp. 291-304. 
CULLER, Jonathan. Literary Theory: a Very Short Introduction. Oxford, Oxford University Press, 1997.

CULLER, Jonathan. "Meaning and Interability", in On Deconstruction: Theory and Criticism after Structuralism. Ithaca/ New York, Cornell University Press, 1992, pp. 110-34. Structuralist Poetics: Structuralism, Linguistics, and the Study of Literature. Eighth printing. Ithaca, Cornell University Press, 1993.

"Poetic of the Novel", in Structuralist Poetics: Structuralism, Linguistics, and the Study of Literature,

1993, pp. 188-238.

"Story and Discourse in the Analysis of Narrative", in The Pursuit of Sign: Semiotics, Literature,

Deconstruction. An Augmented Edition with a new Preface by the Author. Ithaca, Cornell University Press, 2001.

DOSTOIÉVSKI, Fiódor. Memórias do Subsolo. Trad. e pref. de Boris Schnaiderman. 3e ed. São Paulo, Editora 34, 2000.

FACIOLI, Valentim. "Um Homem Bruto da Terra (Biografia Intelectual)", in José Carlos Garbublio e outros (orgs.).

Graciliano Ramos: Antologia e Estudos. São Paulo, Ática, 1987.

FRYE, Northrop; BAKER, Sheridan; PERQUINS, George \& PERKINS, Barbara M. The Harper Handbook to Literature.

Second Edition. New York, Longman, 1997.

GUERIN, Wiffred L. A Handbook of Critical Approaches to Literature. Third Edition. New York/Oxford, Oxford University Press, 1992.

HAWTHORN, Jeremy. Studying the Novel: an Introduction. Second Edition. London, Edward Arnold, 1993.

KAYSER, Wolfgang. Análise e Interpretação da Obra Literária: Introdução à Ciência da Literatura. Trad. de Paulo Quintela. 6.ed. Coimbra, Armênio Amado, 1976.

LINS, Álvaro. "Valores e Misérias das Vidas Secas", in Os Mortos de Sobrecasaca - Ensaios e Estudos. Rio de Janeiro, Civilização Brasileira, 1963.

MEYER, Augusto. Machado de Assis: 1935-1958. Rio de Janeiro, Livraria São José, 1958.

MOISÉS, Massaud. A Criação Literária. 3.ed. São Paulo, Melhoramentos, 1970. Dicionário de Termos Literários. 2.ed. São Paulo, Cultrix, 1978.

MORAES, Denis de. 0 Velho Graça: uma Biografia de Graciliano Ramos. Rio de Janeiro, José Olympio, 1992.

MOURÃO, Rui. Estruturas - Ensaio sobre o Romance de Graciliano. 2.ed. Rio de Janeiro, Arquivo/INL/MEC, 1971.

MUIR, Edwin. A Estrutura do Romance. Tradução de Maria da Glória Bordini. Porto Alegre, Globo, s/d.

RAMOS, Graciliano. Angústia (romance). Rio de Janeiro, José Olympio, 1936.

. Angústia . 2.ed. revista. Rio de Janeiro, José Olympio, 1941.

. Memórias do Cárcere. Rio de Janeiro, José Olympio, 1953.

Angústia. 13.ed. Prefácio de 0tto Maria Carpeaux. Ilustrações de Marcelo Grasmann. São Paulo, Livr.

Martins Editora, 1971.

RICCEUR, Paul. Time and Narrative. Translated by Kathleen McLaughlin and David Pellauer. Chicago/London, The

University of Chicago, 1984, vol. I.

ROCHA, Jucenir. Brasil em Três Tempos: 1500 a 2000. A História é Essa?. São Paulo, FTD, 2000.

SHAW, Harry. Dicionário de Termos Literários. Traduzido do inglês e adaptado por Cardigos dos Reis. Lisboa,

Publicações Dom Quixote, 1978.

SHIPLEY, Joseph T. (ed.). Dictionary of World Literary Terms. Forms, Technique, Criticism. Completely revised and enlarged edtion. Boston, The Writer Inc. Publishers, 1979. 